\title{
First Steps toward Becoming a Teacher: The Experience with the Degree in Primary Education in English
}

\author{
Isabel Alvarez, $\mathrm{PhD}$. (corresponding author) \\ Dept. of Systematic and Social Pedagogy, Autonomous University of Barcelona \\ Building G6, 08193 Bellaterra (Cerdanyola del Vallès) \\ E-mail: Isabel.alvarez@uab.cat \\ Patricia Olmos, PhD. \\ Dept. Applied Pedagogy, Autonomous University of Barcelona \\ E-mail: Patricia.Olmos@uab.cat
}

Received: September 5, 2017 Accepted: December 10, 2017 Published: December 13, 2017

doi:10.5296/elr.v3i2.12286

URL: http://doi.org/10.5296/elr.v3i2.12286

\begin{abstract}
During an academic year took place the experience of observing learning strategies through the development of discursive skills for academic writing with two core subjects in the Degree in Primary Education in English (DPEE). A total of N=219 students' rubrics were analyzed. The methodology was based on two instances: The text-based and documentary data analysis resulted from two factors: (a) implementation of academic writing tasks that regulated the level of student guidance: semi-guided and autonomous in textual, discursive genres: argumentation, critical reflection, and (b) a rubric for students' self-assessment. Results showed that the sample group lacked meta-cognition and had continuous deficiency in oral expression, consequently their progress fell somewhat short of expectations. However, the study resulted in facilitation of pupils' discursive oral production in the first and second years for transfer of knowledge to subsequent academic years and in potential changes to the rubric.
\end{abstract}

Keywords: Active learning, Teaching aims, Teaching techniques, Textual-discursive skills, Assessment rubric 


\section{The Context of Research}

This study aimed (1) to improve students' discursive writing skills during their first and second years in the Degree in Primary Education in English (DPEE) at the Faculty of Educational Sciences of the Autonomous University of Barcelona (In accordance with the 2014 ARMIF call, deployment of the Guideway strategy); (2) to demonstrate how such improvement can enhance students' learning of subject matter. Achievement of these two aims depended on students' receiving sufficient guidance and support on two levels:

a) First level-Discursive writing skills: For 3 months in 2014 (October-December), discursive writing skills were implemented through two tasks, the first semi-guided, aiming to consolidate criteria that students were working toward acquiring. The second, an individual and autonomous task, aimed at assessing the extent to which students applied the previously consolidated criteria. This is how the pedagogical tool's application phase is identified. Recent studies, focused on the development of writing in university foreign language courses (Byrnes, 2012; Knoch et al., 2015; Puebla, 2015; Yasuda, 2011), have contributed the data considered by this study; in other words, these studies show that when students received guidance in their academic writing, they used the newly learned terminology in their composition tasks. Another question worth exploring is the extent to which students sustained this application and transfer over time.

According to Castelló (2009), discursive writing skill involves considering the following points: a) knowing and regulating text composition activities and processes; b) incorporating reasoning processes involved in writing (defining the purpose, activating relevant information, selecting an appropriate genre and type of text); c) planning, researching, selecting, understanding, and synthesizing information from various sources; d) organizing and articulating ideas; e) reviewing and controlling the text being written and, f) considering students' emotional and motivational aspects. In the present study, we have highlighted these points to observe more effectively, both at group and individual levels, discursive writing skills exhibited in the task set.

As for the academic texts, we used to help develop students' discursive writing skills, we chose those which, according to Cassany (2000), were referential and representative, and which served as support for transmission of knowledge. On the other hand, Tapia, Burdiles and Arancibia (2003) defined academic texts as consisting of elaborate discourse, formal and objective language, and precise lexis. Furthermore, in addition to these features, academic texts are characterized by their descriptive or argumentative character, and a high level of abstraction and semantic generalization, with information presented in an orderly, hierarchical fashion and with recourse to inter-text. In the present study, two different text-types were selected: argumentative text for first-year students and critical reflection for second-year students.

b) Second level-Evaluative and transference task (rubric): This level's aim was to facilitate and enhance students' acquisition of meta-cognitive abilities through adaptation of the rubric (Alsina et al., 2017; Andrade \& Du, 2005) in both argumentative writing and critical reflection tasks through three criteria: a) active engagement, b) instructional objectives and c) instructional theories and practices. The reason for using a rubric is the 


\section{Macrothink}

same as that Andrade (2000) offers: in the form of a document, to express expectations of students' written assignments, together with a list of indicators, or what is important, and a description of quality levels, from excellent to most mediocre. A rubric can measure both the process and progress of instruction, just as it can also function as a communication tool to help students understand their performance and/or the result of their response to a given task (Cooper \& Gargan, 2009; Haught et al., 2017; Montgomery, 2000; Moskal, 2000). The rubric can also ensure students' greater understanding of concepts and abilities that, in turn, can result in improved task performance due to more effective feedback (Black et al., 2002; Butler, 1988; Hattie \& Timperley, 2005; Prins, Klein, \& Tartwijk, 2015; Wang, 2016).

Research has shown that both new and experienced teachers vary considerably in their pedagogical foundation (Kleickmann et al., 2012; Quinn, 1997; Schempp et al., 1998) and also in their abilities and attitudes about measuring educational effectiveness (Alkharusi et al., 2011; Green, 1992; Mazloomi \& Khabiri, 2016; Zamora et al., 2016). On the other hand, very important for our research is that teachers who do not use a rubric lack a solid foundation from which to assess their students and, therefore, to interpret results (Davis, 1993; Lovorn \& Rezaei, 2011; Plake et al., 1993; Reynolds-Keefer, 2010; Turley \& Gallagher, 2008). Finally, it must be stressed that, provided they receive adequate training teachers in various disciplines will likely award better final marks to their students, who perform better than they might otherwise (Knoch, Read \& von Randow, 2007; Schafer et al., 2001).

Because teachers in training lack experience with rubrics, employing their use early in training programs is of enormous value; rubrics can help trainees begin to see the learning process as a self-assessment and consciousness-raising tool (Bryant, Maarouf, Burcham, \& Greer, 2016). In this study, once assessment criteria with established indicators were selected for first- and second-year students, bearing in mind their lack of experience in such tasks, using the rubric resulted in qualitative improvement in their self-assessment; students were provided arguments they needed to attribute their learning to the classroom environment. Most importantly, however, rubrics apply not only to the university environment, but also have beneficial effects on very young pupils, even in the first and second years of primary school, that is, on our teacher-trainees' future pupils (Bradford et al., 2015).

\section{Methodology}

In this study, our methodology was mainly qualitative, that is, textual analysis of first- and second-year students' writing tasks guided by rubrics. This was the main data source. For the first Guideway practice, 86 rubrics were sent (15 rubrics for the first year, when the practice was established and performed in small groups of 5 people, and 71 for the second year, when it was performed individually). For the second Guideway practice, 123 rubrics were distributed (71 for the first year, with the practice conducted individually, and 52 for the second year, also individual). A total of 219 rubrics were analyzed according to the data source (i.e., first- and second-year data were analyzed separately) even though, for interpretation of results, data are presented together; we grouped the largest categories according to the three rubric indicators, depending on whether they were from the first or second practice, to make it possible to see connections between the two groups and to extract results for both groups.

In order to analyze key concepts, rubrics were collected and analyzed through the 
SurveyMonkey platform ${ }^{\circledR}$. Both the format of the two practices and the discursive writing styles students were to develop (argumentative in the first year and critical in the second) were common; despite this, they served to identify individual aspects, one of the most significant in the Guideway strategy being the level of guidance for each task. The two practices' formats were characterized by the following features:

a) The first practice was semi-guided and the second, autonomous, both 800 words, elaborating an argumentative text in the first year, and a critical reflection in the second. In the first, semi-guided practice, students watched three videos depicting training sessions; differences and similarities between three very different teaching styles were discussed: a) Primary distance learning (a school in Australia), b) Vittra Learning Space in Sweden and, finally, c) the work being done in a community in San Francisco, where disadvantaged children are provided with a safe space to work, and their work is reinforced. Students received schema for developing an argument (semi-guided task), that is, characteristic features explaining its structure: title, introduction, main body, and conclusion, along with a definition for each part. Examples of semi-guided material include: providing an example in which the topic is explained, questions to be addressed, statements to be made about the book and an example of a good teaching professional (see Table 1).

Table 1. Guidance for composing an argument, including an explanation of its functional structure, an example with pertinent questions, and a student's essay in response to the task (http://www.custom-essays.org/samples/Good_and_Bad_Teachers.html)

\section{Structure:}

Title: (The title of the essay must not be generalized, but detailed. It needs to be concrete and clear. The title of the argumentative essay is basically its thesis statement. Example: "If you want to be healthy, you should not take artificial vitamins").

Introduction: (The introduction must be rather short and include just a couple of phrases referring to the essay's issue. Example: "It is common knowledge that artificial vitamins are very popular nowadays among people of all ages").

Body: The body reveals all the PROs and CONs that the writer chooses to present to the reader. The PROs and CONs need to be carefully chosen as they have a tremendous impact on the argumentative essay's quality. The writer must be able both to support and refute the argument).

Conclusion: The conclusion summarizes the PROs and CONs to prove the thesis statement. The thesis statement must be restated as the essay's bottom line

b) The second practice was an entirely autonomous activity with individual procedures and a mark awarded in December. The level of difficulty was increased from the first practice, and elaboration of a 1000-word text was required in both argument $\left(1^{\text {st }}\right.$ year) and critical reflection $\left(2^{\text {nd }}\right.$ year). The second practice's aim included application of all corrective elements from the first task, so as to demonstrate transference of each subject's content and achievement of greater competence in writing discursive academic texts. First-year students 


\section{Macrothink}

watched the video documentary Waiting for Superman. This documentary featured five stories about North American children's difficulties in accessing a good quality public school." After watching it, our students were asked to choose one of the five episodes and to analyse it from the perspective of one of four worldviews (Pepper, 1942). In their essays, students were to apply the argumentative structure learned in the first practice, and, finally, to apply the indicators (approximately 10) to construct an argument in a manner cognitively superior to that in the first practice. Students had 15 days to complete their texts - a period they much appreciated. Next, the second-year students' task was to compose a critical reflection on a very specific topic within the context of the subject that they were working on, which is one of the educational components, based on a previous individual assignment from a work unit relating to a concrete situation. Students had 3 hours in class to complete their reflection, but beforehand, they had received a range of resources and reading material, so they could prepare to write their essays.

First, the rubric used in this study has been extensively validated in previous studies (Andrade \& Du, 2005; Brookhart, 2003; Moskal, 2003), and Table 2 highlights important aspects of data supply and collection.

Table 2. Three important aspects of the supply and collection of data (Andrade \& Du, 2005)

\begin{tabular}{|c|c|c|c|c|c|}
\hline \multicolumn{3}{|c|}{$\begin{array}{l}\text { Indicators / Type of application } \\
\text { Scheduling } \\
\text { From the two courses }\left(1^{\text {st }}-\text { and } 2^{\text {nd }}-\text { year }\right. \\
\text { Degree in Primary Education in English }) \\
\text { October to December } 2014\end{array}$} & $\begin{array}{l}\text { 1. Active } \\
\text { Engagement } \\
\text { (level of } \\
\text { implication, } \\
\text { involvement) }\end{array}$ & $\begin{array}{l}2 . \\
\text { Instructional } \\
\text { Objectives } \\
\text { (what) }\end{array}$ & $\begin{array}{l}\text { 3. Instructional } \\
\text { Theories and } \\
\text { Techniques } \\
\text { (how) }\end{array}$ \\
\hline $\begin{array}{l}\text { Group } \\
\text { assessment }\end{array}$ & $\begin{array}{l}\text { Individual } \\
\text { assessment }\end{array}$ & $\begin{array}{l}\text { a) What } \\
\text { did you do? }\end{array}$ & & & \\
\hline Activity 1 & Activity 2 & $\begin{array}{l}\text { b) What } \\
\text { do you need } \\
\text { to improve? }\end{array}$ & & & \\
\hline
\end{tabular}

1. Indicators: Three indicators from the original rubric aimed at collecting information on the level of commitment and engagement in the teaching/learning process: level of active engagement, teaching aims (or instructional objectives, course content) and instructional theories and techniques (management of the process).

2. Types of application: a) Intended for small groups (semi-guided) and b) individual (autonomous). This procedure was selected to ensure that students felt comfortable performing the tasks, bearing in mind that both groups faced two major challenges: a) insecurity in tackling a task (argument or critical analysis) whose content was entirely unfamiliar and b) a prior pedagogical process for appropriate application of the rubric and performance of the task (group or individual).

3. Scheduling of activities 1 and 2: As for the rubric, original parameters were used in order to: a) know what students argued and/or analyzed critically, that is, to think about the task's 


\section{Macrothink \\ Education and Linguistics Research \\ ISSN 2377-1356 2017, Vol. 3, No. 2}

content; b) reflect on needed changes to the content.

\section{Analysis and Interpretation of Results}

As previously mentioned, SurveyMonkey is an online platform that makes it possible to generate and analyze discursive text. For this reason, two spaces were used, one for the first year and the other for the second. The total sample was 219 rubrics, a number that amply guarantees results' significance, because the population and the sample represented the same university.

Units of analysis employed were concepts that students used to define each of the three indicators, active engagement, instructional objectives and instructional theories and techniques. Likewise, to determine the data's saturation, a repetition equivalent of superior to $10 \%$ was applied. Given that one of this study's objectives was to improve students' discursive writing skills, in order to ensure clear results, qualitative differentiation was given to units of analysis. In this regard, double differentiation was established: a) concepts that we defined as thematic (words provided by teaching guides) and b) concepts that we defined as learning (students' words resulting from assimilation and appropriation-most valuable because they enabled us to assess the extent to which transfer occurred).

Textual analysis of the two practices in both groups allows us to identify a high percentage of representation of thematic concepts (in bold) and learning (in italics), as Tables 3-6 show.

Table 3. Incidence by percentage, according to thematic or learning concepts (Example: First year students)

\begin{tabular}{|c|c|c|c|c|c|}
\hline$\%$ & Commitment and active engagement & $\%$ & Aims & $\%$ & Techniques \\
\hline \multicolumn{6}{|c|}{ Overall thematic concepts } \\
\hline 40 & Activity & 40 & Learning & 33.3 & Theory \\
\hline 32.3 & Video & 33.3 & Theory & 26.7 & Seminars \\
\hline 26.76 & Essay & 26.6 & Authors & 24 & Essay \\
\hline \multicolumn{6}{|c|}{ Overall learning concepts } \\
\hline 26.6 & Organize & 33.3 & Learned & 46.67 & Useful \\
\hline
\end{tabular}


Table 4. First-year textual analysis results

\begin{tabular}{|c|c|c|c|c|}
\hline & Do & $\begin{array}{l}\text { Essay }(\mathbf{1 6 , 9 )} \\
\text { Doing }(16,9) \\
\text { Teacher }(14,08) \\
\text { Level }(14,08) \\
\text { Video }(\mathbf{1 2 , 6 )} \\
\text { Task }(11,2) \\
\text { Activity }(9,8)\end{array}$ & $\begin{array}{l}\text { Improve }(26,7) \\
\text { Critical }(14,08) \\
\text { Learned }(12,6) \\
\text { Things }(9,8) \\
\text { Authors }(\mathbf{9 , 8 )} \\
\text { Video }(\mathbf{8 , 4 )}\end{array}$ & $\begin{array}{l}\text { Video }(\mathbf{1 9 , 7 )} \\
\text { Essay }(\mathbf{1 6 , 9 )} \\
\text { Improve }(\mathbf{1 2 , 6 )} \\
\text { Practice }(\mathbf{1 2 , 6 )} \\
\text { Doing }(11,2) \\
\text { Teacher }(11,2) \\
\text { Theory }(8,45)\end{array}$ \\
\hline \multirow{2}{*}{$\begin{array}{l}\text { Autonomous } \\
\text { practice } \\
\text { (group } \\
\text { assessment) }\end{array}$} & Did & $\begin{array}{l}\text { Implication }(\mathbf{2 6 , 6 7 )} \\
\text { Responsible } \mathbf{( 2 0 )} \\
\text { Activities }(\mathbf{1 3 , 3 )} \\
\text { Ideas }(13,3)\end{array}$ & $\begin{array}{l}\text { High Level (20) } \\
\text { Learning (20) } \\
\text { Thinking (20) } \\
\text { Apply }(13,3) \\
\text { Methodologies } \\
(13,3) \\
\text { Theory }(13,3)\end{array}$ & $\begin{array}{l}\text { Useful }(46,67) \\
\text { Practice }(33,3) \\
\text { Seminars }(20) \\
\text { Understand the } \\
\text { theory }(13,3) \\
\text { Misconceptions } \\
(\mathbf{1 3 , 3 )}\end{array}$ \\
\hline & Do & $\begin{array}{l}\text { Activity }(\mathbf{4 0}) \\
\text { Improve }(\mathbf{2 6 , 6 )} \\
\text { Organize }(26,6)\end{array}$ & $\begin{array}{l}\text { Practice }(13,3) \\
\text { Working }(13,3)\end{array}$ & $\begin{array}{l}\text { Difficult }(20) \\
\text { Extra }(13,3) \\
\text { Finish }(13,3) \\
\text { Group }(13,3) \\
\text { Theory }(\mathbf{1 3 , 3 )} \\
\text { Understand }(\mathbf{1 3 , 3 )}\end{array}$ \\
\hline \multirow[t]{3}{*}{$\begin{array}{l}\text { Semi-guided } \\
\text { practice } \\
\text { (individual } \\
\text { assessment) }\end{array}$} & Did & $\begin{array}{l}\text { Divided }(13,3) \\
\text { Improved }(\mathbf{1 3 , 3 )} \\
\text { Members }(13,3) \\
\text { Practice }(\mathbf{1 3 , 3 )} \\
\text { Required }(\mathbf{1 3 , 3 )} \\
\text { Responsibility }(13,3)\end{array}$ & $\begin{array}{l}\text { Learning (40) } \\
\text { Theory }(\mathbf{3 3}, \mathbf{3}) \\
\text { Practice }(\mathbf{2 0}) \\
\text { Important }(13,3) \\
\text { Difficult }(13.3)\end{array}$ & $\begin{array}{l}\text { Theory }(\mathbf{3 3}, 3) \\
\text { Seminars }(\mathbf{2 6 . 6 7 )} \\
\text { Activities }(20) \\
\text { Learning }(20) \\
\text { Subject }(13,3)\end{array}$ \\
\hline & Do & $\begin{array}{l}\text { Improving }(36) \\
\text { Group }(33,3) \\
\text { Ideas }(13,3) \\
\text { Implication }(13,3) \\
\text { Organize }(13,3) \\
\text { Trust }(13,3)\end{array}$ & $\begin{array}{l}\text { Theory practice } \\
(\mathbf{3 3 , 3 )} \\
\text { Authors }(\mathbf{2 6 , 6 )} \\
\text { Videos }(\mathbf{2 0 )} \\
\text { Content }(20) \\
\text { Critical }(13,3)\end{array}$ & $\begin{array}{l}\text { Activities (20) } \\
\text { Attention }(20) \\
\text { Sessions }(13,3) \\
\text { Theory }(\mathbf{1 3 , 3 )}\end{array}$ \\
\hline & & $\begin{array}{l}\text { COMMITMENT } \\
\text { AND ACTIVE } \\
\text { ENGAGEMENT } \\
(\%)\end{array}$ & $\begin{array}{l}\text { TEACHING } \\
\text { AIMS } \\
(\%)\end{array}$ & $\begin{array}{l}\text { TECHNIQUES } \\
(\%)\end{array}$ \\
\hline
\end{tabular}




\section{Macrothink}

Education and Linguistics Research

ISSN 2377-1356

2017, Vol. 3, No. 2

\begin{tabular}{|c|c|c|c|c|}
\hline $\begin{array}{l}\text { Autonomous } \\
\text { practice } \\
\text { (individual } \\
\text { assessment) }\end{array}$ & Did & $\begin{array}{l}\text { Video }(\mathbf{3 2 , 3 )} \\
\text { Essay }(\mathbf{2 6 , 7 6 )} \\
\text { Implication }(\mathbf{1 5 , 4 )} \\
\text { Teacher }(15,4) \\
\text { Took }(15,4) \\
\text { Activity }(15,4) \\
\text { Responsible }(\mathbf{9 , 8})\end{array}$ & $\begin{array}{l}\text { Learned }(33) \\
\text { Authors }(19,7) \\
\text { Thinking }(15,4) \\
\text { Problems }(12,6) \\
\text { Educational } \\
\text { System }(11,2) \\
\text { Watching the } \\
\text { video }(\mathbf{9 . 8 )}\end{array}$ & $\begin{array}{l}\text { Essay }(\mathbf{2 4 )} \\
\text { Video }(\mathbf{1 9 , 7 )} \\
\text { Improve }(12,6) \\
\text { Doing }(11,2) \\
\text { Practice }(12,6) \\
\text { Teacher }(11,27)\end{array}$ \\
\hline
\end{tabular}

Table 5. Second-year textual analysis results

\begin{tabular}{|c|c|c|c|c|}
\hline & & $\begin{array}{l}\text { COMMITMENT } \\
\text { AND ACTIVE } \\
\text { ENGAGEMENT (\%) }\end{array}$ & $\begin{array}{l}\text { TEACHING } \\
\text { AIMS (\%) }\end{array}$ & $\begin{array}{l}\text { TECHNIQUES } \\
(\%)\end{array}$ \\
\hline \multirow{2}{*}{$\begin{array}{l}\text { Autonomous } \\
\text { individual } \\
\text { practice }\end{array}$} & Did & $\begin{array}{l}\text { Active }(\mathbf{2 6 , 9 2 )} \\
\text { Order }(26,92) \\
\text { Critical Reflection } \\
(\mathbf{2 3 , 0 8 )} \\
\text { Students }(\mathbf{2 3 , 0 8 )} \\
\text { Practice }(19,23) \\
\text { Level of implication } \\
(\mathbf{1 9 , 2 3 )} \\
\text { Doing the practice } \\
(19,23) \\
\text { Articles }(15,38)\end{array}$ & $\begin{array}{l}\text { Critical } \\
\text { Reflection (26,92) } \\
\text { Think (25) } \\
\text { Useful (25) } \\
\text { High level thinking } \\
(19,23) \\
\text { Practice }(11,64)\end{array}$ & $\begin{array}{l}\text { Knowledge }(30,77) \\
\text { Unit Plan }(\mathbf{2 8 , 8 5 )} \\
\text { Critical Reflection } \\
\mathbf{( 2 3 , 0 8 )} \\
\text { Develop }(23,08) \\
\text { Order }(21,15) \\
\text { Important }(15,38) \\
\text { Theory }(11,64)\end{array}$ \\
\hline & Do & $\begin{array}{l}\text { Unit Plan }(\mathbf{2 8 , 8 5 )} \\
\text { Think (28.85) } \\
\text { Critical Reflection } \\
\mathbf{( 2 5 )} \\
\text { Teacher }(\mathbf{2 3 , 0 8 )} \\
\text { Things }(19,23) \\
\text { Active engagement } \\
(\mathbf{1 1 , 5 4 )}\end{array}$ & $\begin{array}{l}\text { Unit Plan }(\mathbf{3 6 , 6 4 )} \\
\text { Critical } \\
\text { Reflection (30.77) } \\
\text { Order }(21,15) \\
\text { Think }(21.15) \\
\text { Learn }(17,31) \\
\text { Consider }(11,54) \\
\text { Unit Plan }(\mathbf{9 , 6 2 )}\end{array}$ & $\begin{array}{l}\text { Unit Plan }(\mathbf{3 1}, \mathbf{7 4 )} \\
\text { Order }(27,45) \\
\text { Think }(25.49) \\
\text { Doing }(19,61) \\
\text { Critical Reflection } \\
\mathbf{( 1 7 . 6 5 )} \\
\text { Techniques }(\mathbf{1 7 , 6 5 )} \\
\text { Organize }(17,65)\end{array}$ \\
\hline $\begin{array}{l}\text { Semi-guided } \\
\text { group practice }\end{array}$ & Did & $\begin{array}{l}\text { Critical Reflection } \\
\text { (32.86) } \\
\text { Divided the work } \\
(32,86) \\
\text { Experiences }(\mathbf{2 4 , 2 9 )}\end{array}$ & $\begin{array}{l}\text { Knowledge }(25,71) \\
\text { Critical } \\
\text { Reflection (24.29) } \\
\text { Members group } \\
(17,14)\end{array}$ & $\begin{array}{l}\text { Experiences }(\mathbf{3 1}, \mathbf{7 5}) \\
\text { Doing }(26,98) \\
\text { Techniques }(\mathbf{2 3 , 8 1 )} \\
\text { Order }(23,81)\end{array}$ \\
\hline
\end{tabular}




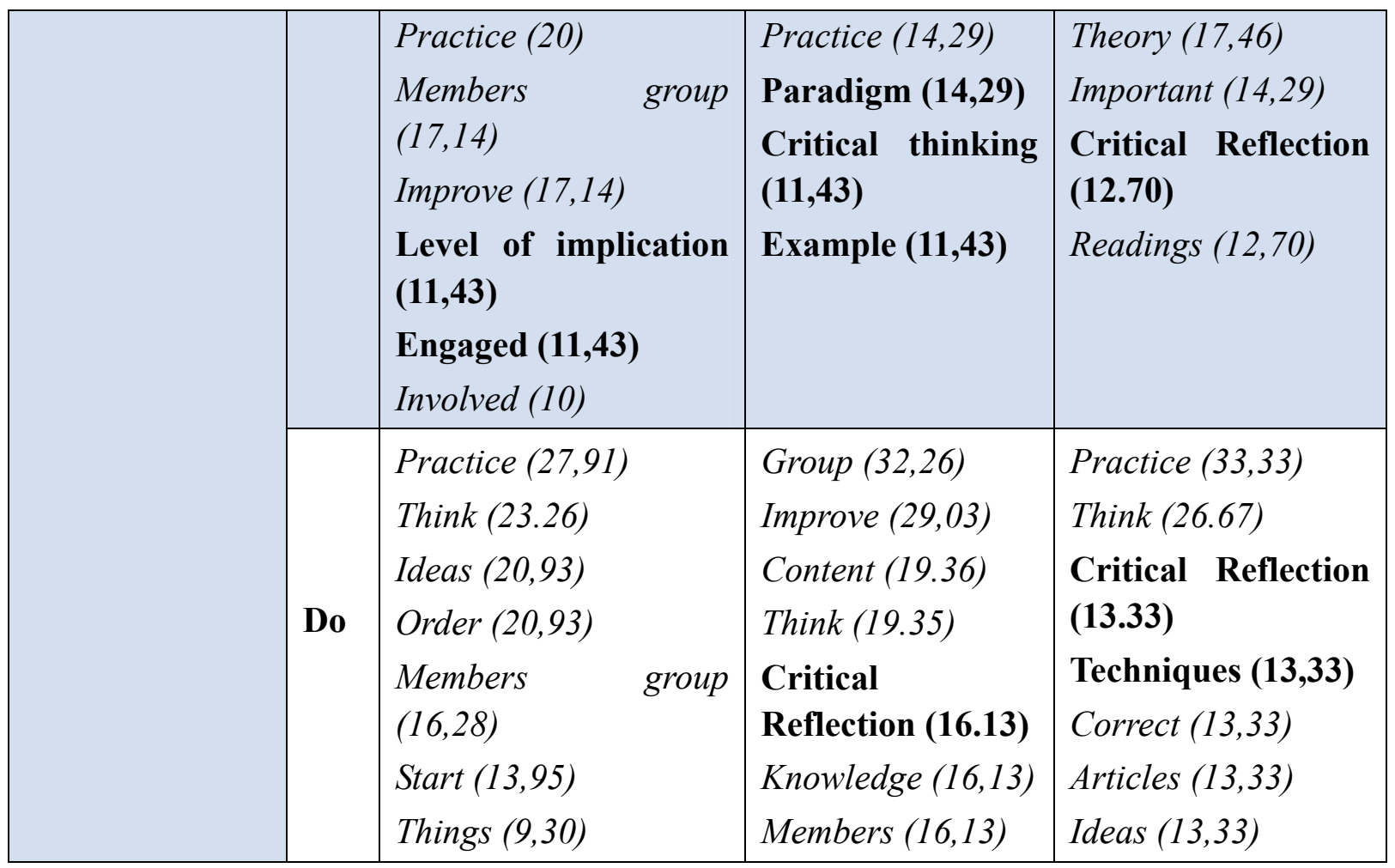

In textual analysis, both groups present very similar progress patterns, that is, identification of words that are:

1) Exclusive to each practice, for example: unit plan, divided work, group, member group, essay

2) Common to the two practices, for example: knowledge, think, order, practice, critical reflection, improve, ideas, theory

3) Denoting different levels of analysis-reflection by students in relation to developed practices, for example: articles, ideas, high-level thinking, useful, misconceptions, organize

This first analysis of the most representative words in both subjects allows us to establish that, although each year, pupils acquire words specific to their courses' subject matter, they also acquire a common set of words that reflect their capability in analysis and reflection in their practices (words like useful, organize, or ideas, among others). The second analysis allows us to group words into categories (learning, resources, reflection, practice, group, management/organization, experience), which, additionally, identify words related to the three assessment indicators (active engagement, teaching aims and techniques) that guide the assessment rubric, as shown in Table 6. 
Table 6. Word frequency per category and three indicators

\begin{tabular}{|c|c|c|c|c|}
\hline \multirow[b]{2}{*}{ Category } & \multirow[b]{2}{*}{ Words } & COMMITMENT & \multirow{2}{*}{$\begin{array}{l}\text { TEACHING } \\
\text { AIMS }\end{array}$} & \multirow[b]{2}{*}{ TECHNIQUES } \\
\hline & & $\begin{array}{l}\text { AND ACTIVE } \\
\text { ENGAGEMENT }\end{array}$ & & \\
\hline \multirow{7}{*}{ Learning } & Knowledge & & 25.71 & 30.77 \\
\hline & Learn & & 17.31 & \\
\hline & Ideas & 20.93 & & 13.33 \\
\hline & Theory & & & 14.50 \\
\hline & Content & & 19.35 & \\
\hline & Improve & 17.14 & 29.03 & \\
\hline & Useful & & 25.00 & \\
\hline \multirow{5}{*}{ Resources } & Techniques & & & 18.26 \\
\hline & Readings & & & 12.70 \\
\hline & Articles & 15.38 & & 13.33 \\
\hline & Unit Plan & 28.85 & 36.64 & 30.11 \\
\hline & Teacher & 23.08 & & \\
\hline \multirow{3}{*}{ Reflection } & $\begin{array}{l}\text { Critical } \\
\text { Reflection }\end{array}$ & 26.98 & 24.53 & 16.69 \\
\hline & $\begin{array}{l}\text { Critical } \\
\text { thinking }\end{array}$ & & 15.33 & \\
\hline & Think & 26.06 & 20.66 & 26.08 \\
\hline \multirow[b]{2}{*}{ Practice } & Practice & 22.38 & 12.97 & 33.33 \\
\hline & $\begin{array}{l}\text { Doing } \\
\text { practice }\end{array}$ & 19.23 & & 23.22 \\
\hline \multirow{3}{*}{ Group } & Group & & 32.26 & \\
\hline & Members & & 16.13 & \\
\hline & $\begin{array}{l}\text { Members } \\
\text { group }\end{array}$ & 16.71 & 17.14 & \\
\hline \multirow{2}{*}{$\begin{array}{l}\text { Management } \\
\text { /Organization }\end{array}$} & Order & 23.93 & 21.15 & 24.14 \\
\hline & $\begin{array}{l}\text { Level of } \\
\text { Implication }\end{array}$ & 15.33 & & \\
\hline \multirow{2}{*}{ Experience } & Experiences & 24.29 & & 31.75 \\
\hline & Examples & & 11.43 & \\
\hline
\end{tabular}

As can be observed, learning and resources categories had the greatest number of words, 
which might show that students' developed practices more greatly impacted the learning process on resources students required to accomplish the tasks. Thus, the indicators teaching aims and techniques also contained the greatest number of words, depending on categories. It is important to bear in mind that categories may identify the same word across several indicators. These results led to the conclusion that the analysis indicators were closely interrelated and that students, on the basis of different practices, made progress in every respect, although teaching aims and techniques were most relevant. Likewise, our results predicted that by applying the Guideway strategy, our sample not only acquired content knowledge but also acquired knowledge and skill in discursive academic writing and adopted new resources, tools, and strategies to help them continue to progress.

On the basis of reflections and commentaries from students, our observation of work dynamics and the project's evolution-among other things - four difficulties and some limitations and deficiencies were identified on the practices' development and on certain elements of students' progress.

The first difficulty has to do with time (especially for second-year students) and the practices' format, rather than content. Students had difficulty organizing the time allowed for completing practices being the main issue the lack of time and for complying with the format in the $2^{\text {nd }}$ practice, 1000 words (Chen, 2015; Révész, Kourtali, \& Mazgutova, 2016). Consequent to these constraints, students tended to associate difficulty with the practice's formal aspects, rather than with the difficulty inherent to its content (Ma, 2013). It should be borne in mind that the practices' level of difficulty increased gradually, for example, the level of guidance provided for the practices' development or the content with which students engaged. Furthermore, none of these students-first- or second-year-had ever before tackled such tasks. Nor had they been required to write in these discursive genres, especially considering the length, 1000 words in English.

In addition, a second difficulty was lack of transfer of first-practice learning to development of the second practice. Two factors contributed to this:

1) During the first semi-guided activity, students acquired knowledge and skills like using quotations, structuring an argument, critical reflection, orientation regarding established criteria, use of certain learning resources, level of quality required, and so on. However, some mistakes made in the first practice reappeared in the second, autonomous practice. This suggests that students' difficulty has to do with inability to transfer acquired knowledge.

2) The second factor was deficiency in group transfer of knowledge acquired during the first practice to development of the individual, second practice. Transferring knowledge from a group to an individual task poses certain added difficulties - identifying and remembering what was learned within the formal structure in which it was learned (Cheng, 2016; Stognieva, 2016). In other words, working in small groups in which everyone collaborates and ideas are collected under a group identity, but with a great deal of internal diversity, is not the same as working individually (Rahimi \& Tavakoli, 2016; Rodríguez \& Roehr-Brackin, 2015). Needless to say, this entails greater engagement by teachers; they need to understand that both contexts, group and individual, impinge directly on the learning process and that both contribute in the same way to subsequent transfer of knowledge. This difficulty 
contradicts Dewaelsche's (2015) conclusions about when individual activities precede group activities.

3) A third interesting difficulty was that students associated directly with the subject matter's vehicular language and their level of mastery. Both first- and second-year students attributed their negative results to working-group members' differing levels of language proficiency. Students considered their level of English a factor contributing positively or negatively to the working group's dynamic and to results of the learning process; they concurred in attributing negative results to students with a lower mastery level. This response coincides with studies by Pérez Ruiz (2014) and Lorenzo (2017).

Likewise, language was also a factor determining the classroom communication process, that is, communicative interaction established between teachers and students (Blair, 2016). Quite commonly, the teacher asked students a question, but got no answer. Among the students, who habitually speak Catalan together, English can be problematic in informal conversation (Rosas, 2016) because of students' varying English language skills, just as Erixon and Erixon (2016) and Talalakina (2015) reported.

A final difficulty had to do with working groups' internal management. Those who formed groups attached great importance to members' levels of active engagement and highlighted lack of engagement as a major problem. This issue is difficult to address; it can lead to internal conflicts, as demonstrated in Lodej (2015) and Popkova (2015).

In addition to these difficulties, a whole range of deficiencies were also identified. Deficiencies were experienced as limitations in conducting practices and/or activities. Most significant was lack of meta-cognition of the rubric as a learning tool, following Chen and Myhill (2016) and Perales and Reyes (2015). In completing practices, students in this study followed the rubric as a task in its own right, with a view to self-evaluation. However, they did not view it as a learning tool or resource. For example, students did not use the rubric to reflect on their errors, in order to improve their performance in the practices and in their learning process. Nor did they reflect on the gradual increase in the difficulty level of each practice. Instead, they tended to associate difficulty with formal aspects (e.g., work-group management, level of English), which, as mentioned, led to repetition of the same work patterns from one practice to the next. In this regard, students were not capable of regulating their learning process through the rubric, which they should have seen not only as an assessment instrument, but also as a resource for learning enhancement.

Despite these difficulties and limitations, the Guideway strategy's application also revealed many examples of genuine progress. In addition to positive details mentioned about discursive writing skills, we want first to indicate students' positive evaluation of the teachers' role in development of the practices and, secondly, the use of certain teaching-learning strategies. Coinciding with Brooks (2016), Evaldsson and Melander (2016), Galichkina (2016), Lee and Lyster (2016) and Valieva (2016), students rated the teachers' guidance very highly, also their commitment and the resources they made available. As for instructional strategies, most highly rated was the debate-and-discussion technique used to share results of practices and working groups. Students considered this a good learning technique and a very useful resource for developing their thinking and reflecting on their errors. This is paradoxical, of course, considering lack of reflection on mistakes using the 
rubric. Furthermore, the Guideway strategy's most highly rated aspects were:

1) The overall view of the practice: Working groups often conducted the practices in sections, thereby losing sight of the broader, entire picture. Having to deliver presentations and engage in debates on the practice meant that fragmentation gave way, in the debate space, to a broader, more integrated approach to the content (Rodríguez \& Ferreira, 2015).

2) Oral expression: Oral presentation of the practices' result raised students' awareness of what they were learning (Rico \& Níkleva, 2015).

3) Contrasting viewpoints: Debate provided an opportunity for exchange of opinions, ideas, points of view, and even different working models related to the same subject or activity. Students highly appreciated this learning outcome.

\section{Conclusions and Future Projection}

Clearly, results obtained from application of the Guideway strategy are very important, significant, and relevant for reaching its aims and, especially, for the progress student-participants achieved toward the Degree in Primary Education: Students not only acquired specific knowledge of subject matter, but they also learned to adopt new resources, tools, and strategies for moving their learning forward.

Even so, we are conscious of the necessity to continue working along these lines and to innovate improvements to the Guideway strategy. First, we need to introduce modifications to the rubric relating to analysis of moments in time, to establish clearer progression, in order to determine whether actual improvement has occurred; in particular, we envisage the need to include a future moment (will). Secondly, because students did not follow rubrics correctly, a preliminary training session should be implemented before application to enhance the instrument's effectiveness. Finally, although discursive writing skill has been recorded and analyzed, we might include techniques enabling us to record and analyze students' discursive skills in other methodological strategies used, such as debates and presentations.

This study has opened a line of research so that the Guideway strategy can continue to be explored, developed, and improved. As our study demonstrated, it is an effective pedagogical instrument for improving students' learning through development of a key skill: linguistic competence applied to discursive writing skill.

\section{References}

Alsina, A., Ayllón, S., Colomer, J., Fernández-Peña, R., Fullana, J., Palllisera, M., Pérez-Burriel \& Serra, L. (2017). Improving and evaluating reflective narratives: A rubric for higher education students. Teaching and Teacher Education, 63, 148-158. https://doi.org/10.1016/j.tate.2016.12.015

Blair, A. (2016). Academic uses of language (re)defined: A case of emergent bilinguals engaging in lanuages and literacies in and outside of school. Linguistics and Education, 35, 109-119. https://doi.org/10.1016/j.linged.2016.07.003

Brooks, M. D. (2016). "Tell me what you are": An investigation of five Latina LTELs constructing meaning with academic texts. Linguistics and Education, 35, 1-14. https://doi.org/10.1016/j.linged.2016.03.001

Bryant, C. L., Maarouf, S., Burcham, J., \& Greer, D. (2016). The examination of a teacher 
candidate assessment rubric: A confirmatory factor analysis. Teaching and Teacher Education, 57, 79-96. https://doi.org/10.1016/j.tate.2016.03.012

Chen, A.-H. (2015). EFL Learner's Perspectives upon Creating Contextual English for Specific Purposes. Education and Linguistics Research, 1(2), 30-41. https://doi.org/10.5296/elr.v1i2.8240

Chen, H., \& Myhill, D. (2016). Children talking about writing: Investigating metalinguistic understanding. Linguistics and Education, 35, 100-108. https://doi.org/10.1016/j.linged.2016.07.004

Cheng, T. P. (2016). Authentic L2 interactions as material for a pragmatic awareness-raising $\begin{array}{llll}\text { activity. } \quad \text { Language } & \text { awareness, } & \text { 25(3), }\end{array}$ https://doi.org/10.1080/09658416.2016.1154568

Dewaelsche, S. A. (2015). Critical thinking, questioning and student engagement in Korean university English courses linguistic and Education, 32, 131-147.

Erixon Arreman, I., \& Erixon, P. O. (2016). Professional and academic discurse-Swedish student teacher's final degree project in Early Childhood Education and Care. Linguistics and Education.

Evaldsson, A. C., \& Melander, H. (2016). Managing disruptive student conduct: Negative emotions and accountability in reproach-response sequences. Linguistics and Education.

Galichkina, E. (2016). Developing teacher-trainees' assessment awareness in the EFL classroom through project-based learning activity. Journal of Languaje \& Education, 2(3), 61-70. https://doi.org/10.17323/2411-7390-2016-2-3-61-70

Haught, P. A., Ahern, T. C., \& Ruberg, L. F. (2017). Student Awareness and Use of Rubrics in Online Classes. Higher Education Studies, 7(1), 69-77. https://doi.org/10.5539/hes.v7n1p69

Lee, A. H., \& Lyster, R. (2016). Effects of Different Types of Corrective Feedback on Recpetive Skills in a Second Language: A Speech Perception Training Study. Language Learning, 66(4), 809-833. https://doi.org/10.1111/lang.12167

Lodej, M. (2015). Reading accuracy in EFL students with a transparent L1 background-a casee study from Poland. Journal of Language \& Education, 1(2), 35-40. https://doi.org/10.17323/2411-7390-2015-1-2-35-40

Lorenzo, F. (2017). Historical literacy in bilingual setting: Cognitive academic language in CLIL history narratives. Linguistics and Education, 37, 32-41. https://doi.org/10.1016/j.linged.2016.11.002

Ma, Q. (2013). Matching vocabulary learning process with learning outcome in L2 academic writing: an exploratory case study. Linguistic and Education, 24, 237-246. https://doi.org/10.1016/j.linged.2012.11.002

Mazloomi, S., \& Khabiri, M. (2016). The impact of self-assessment on language learners' writing skill. Innovations in Education and Teaching International, 1-10. https://doi.org/10.1080/14703297.2016.1214078

Pepper, S. C. (1942). World Hypotheses: An study in Evidence. Berkeley. University of California Press.

Perales, M. D., \& Reyes, M. R. (2015). The impact of a linguistic intervention on rhetorical 
inferential comprehension and metacognition in EFL academic Reading: a quasi experimental, mixed-methods study. Revista Signos. Estudios de Lingüística, 48(89), 332-354. https://doi.org/10.4067/S0718-09342015000300003

Pérez Ruiz, J. (2014). La contribución del oyente a la interacción oral en Español como Lengua Extranjera. Un estudio compartivo. Revista Signos. Estudios de Lingüística, 47(86), 486-513.

Popkova, E. (2015). The backyard of EFL teaching: issues behind L1 prosodic interference in Russian English. Journalof Language \& Education, 1(4), 37-44. https://doi.org/10.17323/2411-7390-2015-1-4-37-44

Prins, F. J., Klein, R. De, Tartwijk, J. van (2015). Students' use of a rubric for research theses. Assessment \& Evalution in Higher Education, 42, 128-150. https://doi.org/10.1080/02602938.2015.1085954

Rahimi, M., \& Tavakoli, M. (2016). The effect of learning English as a foreign language on the temporal and spatial perception of Persian learners. Revista Signos. Estudios de Lingüistica, 49(92), 403-424. https://doi.org/10.4067/S0718-09342016000300007

Révész, A., Kourtali, N. E., \& Mazgutova, D. (2016). Effects of Task Complexity on L2 Writing Behaviors and Linguistic complexity. Language Learning, 67(1), 208-241. https://doi.org/10.1111/lang.12205

Rico, A. M., \& Níkleva, D. (2015). Análisis de la competencia lingüístico-discursiva escrita de los alumnos de nuevo ingreso del Grado de Maestro en Educación Primaria. Revista $\begin{array}{llll}\text { Signos. } & \text { Estudios de } & \text { Lingüística, } & 49(90),\end{array}$ https://doi.org/10.4067/S0718-09342016000100003

Rodríguez, A., \& Ferreira, R. A. (2015). Reconocimiento visual y categorización semántica de palabras nuevas en inglés como lengua extranjera (L2): El rol de la lectura y las actividades explícitas de vocabulario. Revista Signos. Estudios de Lingüística, 48(89), 379-399. https://doi.org/10.4067/S0718-09342015000300005

Rodríguez, L. H., \& Roehr-Brackin, K. (2015). Perceived Learning Difficulty and Actual Perfomance: Explicit and Implicit Knowledge of L2 English Grammar Points among Instructed Adult Learners. Studies in Second Language Acquisition, 38(2), 317-340.

Rosas, M. (2016). Comunication strategies used by different level L2 English learners in oral interaction. Revista Signos. Estudios Lingüísticos, 49(90), 71-93. https://doi.org/10.4067/S0718-09342016000100004

Stognieva, O. (2016). Efficiency of individualized resources in the Russian EFL classroom. Journal of Language \& Education, 2(4), 63-74. https://doi.org/10.17323/2411-7390-2016-2-4-63-74

Talalakina, E. (2015). Fostering Positive Transfer thrugh Metalinguistic Awareness: A Case for Parallel Instruction of Synonyms in L1 and L2. Journal of Language \& Education, 1(4), 74-80. https://doi.org/10.17323/2411-7390-2015-1-4-74-80

Valieva, F. (2016). Resiliency in Education: the Case of Foreign Language Teachers. Journal of Language \& Education, 2(3), 54-60. https://doi.org/10.17323/2411-7390-2016-2-3-54-60

Wang, W. (2016). Using rubrics in students self-assessment: student perceptions in the 


\section{Macrothink}

Education and Linguistics Research

ISSN $2377-1356$ 2017, Vol. 3, No. 2

English as a foreign language writing contextr. Assessment \& Evaluation in Higher Education, 1-13.

Zamora, A., Suárez, J. M., \& Ardura, D. (2016). Error detection and self-assessment as mechanisms to promote self-regulation of learning among secondary education students. The Journal of Educational Research. https://doi.org/10.1080/00220671.2016.1225657

\section{Copyright Disclaimer}

Copyright reserved by the author(s).

This article is an open-access article distributed under the terms and conditions of the Creative Commons Attribution license (http://creativecommons.org/licenses/by/3.0/). 